African Research Review

AN INTERNATIONAL MULTI-DISCIPLINARY JOURNAL, BAHIR DAR, ETHIOPIA

AFRREV VOL. 11 (3), SERIAL NO. 47, JULY, 2017: 187-196

ISSN 1994-9057 (Print)

ISSN 2070-0083 (Online)

DOI : http://dx.doi.org/10.4314/afrrev.v11i3.18

\title{
Strategic Management Foundations and Employee Performance of Aluminium Companies in Delta State
}

\author{
Nzewi, Hope Ngozi \\ Department of Business Administration \\ Faculty of Management Sciences \\ Nnamdi Azikiwe University, Awka \\ Onwuka, Ebele Mary \\ Department of Business Administration \\ Faculty of Management Sciences \\ Nnamdi Azikiwe University, Awka \\ Anambra State, Nigeria \\ E-mail: ebyonwuka@gmail.com
}

\section{Okoro, Olu Bernard}

Department of Business Administration

Faculty of Management Sciences

Nnamdi Azikiwe Univeristy, Awka

Anah, Stanley

Department of Business Administration

Faculty of Management Sciences

Chukwuemeka Odumegwu Ojukwu University, Uli

Anambra State, Nigeria 


\begin{abstract}
Strategic management foundation is a fundamental part of any organization. Strategic management comprise of environmental scanning, strategy formulation, implementation, evaluation and control. Through this process, an organization plans its activities which shall be profitable to the firm. Employee performance is the degree of an achievement to which an employee fulfils the organizational mission at workplace. It implicitly takes into consideration a range of variables at both organizational level and departmental level. The present study determined the relationship between strategic management foundations and employee performance of Aluminium companies in Delta State. The study adopted a descriptive survey design. One research question guided the study and one hypothesis was tested at 0.05 level of significance. Data was collected with the use of questionnaire and analysis was done using mean and standard deviation. The study revealed that strategic management foundation is positively related with employee performance. It was recommended among others that, since strategic management has positive relationship with employee performance in aluminium companies, strategic management practices should be adopted within the organization. In this way, employee performance and overall organizational effectiveness can be enhanced.
\end{abstract}

Key Words: Strategic management, foundations, Employee Performance

\title{
Introduction
}

In the present age of technology and globalization, organizations are seeking to create much competition between them, taking more market, more customers and more sales. Rapid changes stemming from globalization, advancement or information system and other factors have resulted in competition among difference sectors of the economy. As a result of this, many organizations are driven by the market to set their goals in their performance. These goals are set with the purpose of: cost reduction, achieving sales levels, increasing the number of customers, increasing the market percentage, improving productivity quality and innovative products. The realization of these goals can only be achieved through the employees of the organization. This is because the performance of the employees remains one of the greatest keys to organizational effectiveness which is achievable using the relevant business strategies.

Therefore, strategic management is considered to be the most important practice which distinguishes organizations from one another. Strategic management seems to be the key process to achieving organizational vision, strategy and objectives. Many large organizations appear to implement strategic management practices in order to ensure that they fit within their environment. According to Dudin (2013), in today's business environment, business organizations are facing fierce competition in domestic and global markets. This implies that to survive and develop, business organizations may have to implement strategic management tools as means of increasing their competitiveness in the market.

It appears that there is neither clear-cut definition nor agreement on strategic management components. For instance, Dess, Lumpkin and Taylor (2005) defined strategic management as the analysis, decisions, and actions an organization undertakes in order to create and sustain competitive advantages. That implies focusing on the basic question: How should organizations compete in order to create competitive advantages

Copyright $\left({ }^{\circ}\right.$ International Association of African Researchers and Reviewers, 2006-2017: www.afrrevjo.net.

Indexed African Journals Online: www.ajol.info 
in the marketplace? In the view of Price (2006), strategic business is divided into basic components which include vision, mission, values, objectives, and plans. Similarly, Mackie (2008) observed that strategic management refers to a set of processes comprising strategy formulation, strategy implementation, monitoring and control. The strategic management process is a cyclical and on-going process. It is a stream of decisions and actions, which leads to the development of an effective strategy or strategies to help achieve corporate objectives in a competitive most way. Furthermore, Abubakar, Tufail, Yusuf and Virgiyanti (2011) described strategic management as a concept that concerns with making decisions and taking corrective actions to achieve long term targets and goals of an organization. The importance of strategic management in a firm is best determined by analyzing relationship between strategic management and organizational performance. Moreover, Mahoney (2012) elaborated that strategic management addresses the organizational structure, resources and capabilities, and the strategic positioning of the organization to create, capture, and sustain competitive advantage. Similarly, Dudin (2013) explained strategic management as a process in a firm consists of setting the vision, mission and goals, analysis of external and internal business environment, selection of a favorable strategy, strategic planning, and proposals for organizational, administrative changes, setting measures on control systems and strategy implementation, and evaluation of the strategy.

In the current highly competitive globalized market, it is essential to analyze, evaluate and manage the organization's strategy to improve organizations' performance. UNDP (2008) reported that in the absence of quantitative and qualitative follow up on emerging outcomes, informed decision making for strategic management becomes a challenge. The lack of an effective monitoring and evaluation system limits informed strategic management. This is because strategic management is about the management of the totality of an organization, in order to create the future. Hence, there is a very important relationship between strategic planning and performance management. Performance management has to do with setting and achieving goals at the employee level, and identifying and fixing barriers related to achieving those goals. The application and use of methods of strategic management by the production or manufacturing companies lead to achieve several benefits and features for these companies, which assist it to achieve its goals and objectives and the performance of its functions in the strategic-range.

Aluminum companies seem to be at the top most part of the production industry because they are vast in the operation both in manufacturing and construction. Aluminium is the third most abundant element in the Earth's crust (after oxygen and silicon) and it is most abundant in metals. Aluminium makes up about $8 \%$ of the crust mass, though it is less common in the mantle below. Aluminum metal is so chemically reactive that native specimens are rare and limited to extreme reducing environments. Aluminum companies are so vast in their operations both in manufacturing construction and can be found in every state of the country. The focused aluminium manufacturing companies include: Asaba Aluminum Company, Agen Aluminum Company, Flight Aluminum Company, Tower Aluminium Company and Wich-Tech Aluminum Company all located in Delta State. Therefore, this study is designed to determine the impact of strategic management foundations on employees' performance of Aluminium companies in Delta State of Nigeria.

Copyright $\left({ }^{\circ}\right.$ International Association of African Researchers and Reviewers, 2006-2017: www.afrrevjo.net.

Indexed African Journals Online: www.ajol.info 


\section{Statement of the Problem}

Many authors and researchers have noted that it is important for organizations to measure what they would like to manage. Dauda, (2010) recommended that investors and managers should make use of strategic management to improve their organizations actual performance at all times. In spite of this overwhelming importance of strategic management foundations to manufacturing industries particularly aluminum industry, many companies in Nigeria seems not to appreciate the role strategic management elements plays in enhancing employee performance. Abubakar, et al (2011) stated the importance of strategic management in a firm can be answered by analyzing relationship between strategic management and performance. Hence the need to determine the relationship between strategic management foundations and employee performance of aluminum companies in Delta State.

\section{Objectives of the Study}

The main objective of the study was to determine the relationship between strategic management foundations and employee performance of Aluminum companies in Delta State. Specifically, the study sought to assess the nature of relationship between internal processes and employee performance of aluminium companies in Delta State

\section{Research Questions}

The study was guided by the following research question:

1. What is the nature of relationship between internal processes and employee performance of aluminum companies in Delta State?

\section{Conceptual Review}

Strategic Management: Strategic management is the process and approach of specifying an organization's objectives, developing policies and plans to achieve and attain these objectives, and allocating resources so as to implement the policies and plans (David, 2005). Strategic management is the process of examining both present and future environments, formulating the organizations objectives, implementing and controlling decisions focused on achieving these objectives in the present and future environments (Adeleke, 2008). Strategic management is the process and approach of specifying an organization's objectives, developing policies and plans to achieve and attain these objectives, and allocating resources so as to implement the policies and plans (David, 2005).

Performance: Performance refers to the ability (both physical and psychological to execute a specific task in a specific manner that can be measured as high, medium or low in scale. The word 'performance' cam be used to describe different aspects such a societal, individual, employees, organizational etc. Employees' performance is the degree of an achievement to which an employee is fulfil the organizational mission at workplace (Cascio, 2006). Performance has been perceived differently by various researchers, but most of the scholars relate performance with measurement of transactional efficiency and effectiveness towards organizational goals. According to Cascio (2006), the job of an employee is build up by degree of achievement of a particular target or mission that defines boundaries of performance. Certain researchers have identified different thought, attitudes and beliefs of performance as it helps in measurement of input and output efficiency measures that lead to transactional

Copyright (c) International Association of African Researchers and Reviewers, 2006-2017: www.afrevjo.net.

Indexed African Journals Online: www.ajol.info 
association (Stannack, 1996). Employees' performance is the degree of an achievement to which an employee fulfils the organizational mission at workplace (Cascio, 2006).

The capability of an organization to establish perfect relationship with resources presents effective and efficient management of resources (Daft, 2000). In order to achieve goals and objectives of organization strategies have been designed based upon organizational performance (Richardo, 2001). The equity based upon high returns helps in effective management of organization resources so that performance improves (Ricardo, 2001).

\section{Empirical Studies}

Lawal, Elizabeth, \& Oludayo (2012) studied the effect of strategic issue management on organizational performance. The main objective of this study was to explore the links between strategic issue management activities and organizational performance. The methodology of this study a survey research design was adopted. The sample size was 100 respondents using simple random and judgmental sampling technique and Questionnaire was used as data collection tool. The study revealed some evidence that issues management is indeed a strategic organizational function in the sense that the adoption of issues management techniques can improve the performance and relative standing of organization that are with different societal and political issues.

Similarly, Ajao and Grace (2012) carried out a study on the effects of strategic planning on corporate performance in university education: a study of Babcock University. The main purpose of this study was to find the effect of Strategic Planning on Corporate Performance using Babcock University as the case study and how this has impacted on the management efficiency and effectiveness as strategic planning is essential in corporate organizations. The research design adopted for this study was the survey design. The sample size was 283 and questionnaire was used as data collection tool. From the findings of this study, it has been established that effective strategic planning indeed has a positive impact on performance. Although formal planning only may not bring about better performance, effective implementation will suffice.

Muogbo (2013) carried out a study titled the impact of strategic management on organizational growth and development (a study of selected manufacturing firms in Anambra state). The main objective of this study was to investigate the impact of strategic management on organizational growth and development of selected manufacturing firms in Anambra State. The methodology of this study was Survey research used in this study. The sample size was 63 respondents selected from 21 manufacturing firms across the three senatorial zones of Anambra State were sampled ( 3 from each firm). The study thus concluded that though strategic management is not yet a common business practice among manufacturing firms in Anambra State, it has been identified as veritable tool for improving the competitiveness, performance levels, and structural development of manufacturing firms in Anambra State in particular and Nigeria in general.

Copyright $\left({ }^{\circ}\right.$ International Association of African Researchers and Reviewers, 2006-2017: www.afrrevjo.net.

Indexed African Journals Online: www.ajol.info 


\section{Method}

The study employed survey design to determine the relationship between the nature of relationship strategic management foundation and employee performance of aluminium companies in Delta State.

The population of the study consisted of 123 employees of five selected aluminium companies in Delta State. The distribution of population of employees according to their companies is shown below:

\begin{tabular}{|l|l|l|}
\hline S/N & Name of Aluminium Company & Employees \\
\hline 1 & Asaba Aluminium Company & 22 \\
\hline 2 & Agen Aluminium Company & 24 \\
\hline 3 & Flight Aluminium Company & 31 \\
\hline 4 & Tower Aluminium Company & 27 \\
\hline 5 & Wich-Tech Aluminium Company & 19 \\
\hline & Total & 123 \\
\hline
\end{tabular}

The entire population was used for the study since the number is small and relatively manageable, hence there was no sampling.

A 20-item questionnaire was used as instrument for the study. The research instrument has two parts - Part A and Part B. Part A contains information on the respondent's biographic data. Part B contains 20 items in line with research question raised for the study. The instrument was structured to elicit information from the assessment of respondents on a 4-point rating scale as follows:

$\begin{array}{lll}\text { Strongly Agreed } & \text { (SA) } & 4 \\ \text { Agreed } & \text { (A) } & 3 \\ \text { Disagreed } & \text { (D) } & 2 \\ \text { Strongly Disagreed } & \text { (SD) } & 1\end{array}$

The instrument used to collect data for the study was subjected to content and face validity by some experts in the field of measurement and evaluation to ensure that the items of the questionnaire capture the variables of the study. Their observations were effected on the questionnaire before final copy was written.

Data were collected from primary and secondary sources. The primary data involves obtaining information directly from the respondents through a structured questionnaire, while the secondary data involved the use of journal articles and materials from the internet. The questionnaire constructed was administered by the researcher to the respondents with the aid of research assistant. The researcher was able to collect some of the questionnaire on the spot while others were collected after few days. Out of a total of 123 questionnaire distributed 109 copies were returned base on which analysis for this study was done. In analyzing the data to be collected from the instrument administered, simple mean and standard deviation were used to analyze the responses for research question while $\mathrm{z}$ test was used for testing hypothesis. Any item with a

Copyright (C) International Association of African Researchers and Reviewers, 2006-2017: www.afrrevjo.net.

Indexed African Journals Online: www.ajol.info 
mean rating that is equal to or greater than 2.5 was considered 'Agreed' while any item with a mean rating that is less than 2.5 was considered 'Disagreed'.

\section{Result}

Research Question: What is the nature of relationship between internal processes and employee performance of aluminum companies in Delta State?

Table 1: Respondents' Mean Rating on the Nature of Relationship Between Internal Processes and Employee Performance ( $N=117)$

\begin{tabular}{|c|c|c|c|c|}
\hline & Items & Mean & $\begin{array}{c}\text { Std. } \\
\text { Deviation }\end{array}$ & Remark \\
\hline 1 & Clear strategic goals & 3.89 & 0.661 & Agreed \\
\hline 2 & Participation in decision making & 3.89 & 0.608 & Agreed \\
\hline 3 & Multisource of data & 3.90 & 0.671 & Agreed \\
\hline 4 & Production strategies implementations & 3.88 & 0.650 & Agreed \\
\hline 5 & Introducing new products in suitable time & 3.76 & 0.567 & Agreed \\
\hline 6 & $\begin{array}{l}\text { Internal processes aim to create competitive } \\
\text { advantages }\end{array}$ & 3.88 & 0.668 & Agreed \\
\hline 7 & Internal processes aim to reduce cost & 3.82 & 0.663 & Agreed \\
\hline 8 & $\begin{array}{l}\text { Suitable initialization of resources to create } \\
\text { accepted revenue }\end{array}$ & 3.90 & 0.601 & Agreed \\
\hline 9 & Follow quality guides & 3.08 & 0.691 & Agreed \\
\hline 10 & Suitable training programs for employees & 3.94 & 0.755 & Agreed \\
\hline 11 & Training programs aim to improve quality & 3.10 & 0.654 & Agreed \\
\hline 12 & Developing innovation capabilities & 3.07 & 0.684 & Agreed \\
\hline 13 & Creative ideas to develop performance & 3.99 & 0.662 & Agreed \\
\hline 14 & $\begin{array}{l}\text { Company concern about adding value to } \\
\text { employees }\end{array}$ & 3.02 & 0.580 & Agreed \\
\hline 15 & Using latest technology for $R \& D$ & 3.93 & 0.650 & Agreed \\
\hline & Grand Mean & 3.242 & 0.413 & Agreed \\
\hline
\end{tabular}

The data in the table 1 revealed the impact of internal processes elements of strategic management on employees' performance in aluminium companies in Delta State. All the items in the table received mean scores above 2.50 which indicate that the respondents agreed that strategic management of internal process of organization has positive relationship with employee performance. The grand mean of 3.05 further shows that the respondents agreed that strategic management of internal process has positive relationship with employee performance of aluminium companies in Delta State. 


\section{Discussion of Results}

This study empirically tested the nature of relationship between strategic management elements and employees' performance in aluminium companies in Delta State. The findings also revealed that there is positive relationship between strategic management elements and employee performance in aluminium companies in Delta State. The findings of this work agreed with Lawal, Elizabeth, \& Oludayo, (2012), who carried out a study to determine the effect of strategic issue management on organizational performance. The study revealed some evidence that issues management is indeed a strategic organizational function in the sense that the adoption of issues management techniques can improve the performance and relative standing of organization that are with different societal and political issues.

The study also demonstrated that strategic management of internal processes of aluminium companies has positive relationship with employee performance of these firms. This finding is in agreement with Dauda, Akingbade, \& Akinlabi (2010) who carried out a study titled strategic management practice and corporate performance of selected small business enterprises in Lagos metropolis. The findings of the study showed that strategic management has an effect on the market share of SBEs. Also, implementation of strategic management has a positive relationship with organizational profitability

Finally, the study revealed that learning and growth of employee as strategic management element has positive relationship with employee performance in aluminium firms in Delta State. This result agreed with Dauda, et. al. (2000) who examined the influence of strategic management on corporate performance in selected small-scale enterprises in Lagos Metropolis, Nigeria. Findings of the study revealed that strategic management practices like learning and growth enhance both organizational profitability and company market share.

\section{Conclusion}

Based on the findings of this study, it is concluded that there is positive relationship between strategic management foundations and employee performance of aluminium companies in Delta State. The study also concluded that strategic management elements particularly, internal process and learning and growth of employees have positive relationship with employee performance of aluminium companies in Delta State.

\section{Recommendations}

Based on the findings, the following recommendations were made:

i. In aluminium companies, strategic management practices should be adopted within the organization. In this way, employees' performance and overall organizational effectiveness can be enhanced

ii. Managers in the Aluminium companies should ensure that strategic management of their internal processes as is holds remarkable impact on the performance of their employees.

iii. Management practices should ensure that there is unwavering emphasis on strategic management in the form of employees learning and growth as it determine to a very large extent the impact and profitability of the employees.

Copyright (c) International Association of African Researchers and Reviewers, 2006-2017: www.afrevjo.net. 


\section{References}

Abubakar, A. H., Tufail, M. A., Yusof, M. N., \& Virgiyanti, W. (2011). Implementation of strategic management practices in the Malaysian construction industry, 13:1733.

Adeleke, O. A. (2008). Strategic management practice and corporate performance. International Journal of Business and Management. 2(6), 14 - 22.

Ajao, O. S., \& Grace, M. O. (2012). The effects of strategic planning on corporate performance in university education: A study of Babcock University. Arabian Journal of Business and Management Review 2(4), 134 - 142.

Akingbade, A. W. (2007). Strategic management practice and corporate performance. International Journal of Business and Management. 2(5), $34-42$.

Dauda, A.Y., Akingbade, A.W., \& Akinlabi, B. H. (2010). Strategic management practice and corporate performance of selected small business enterprises in Lagos metropolis. International Journal of Business and Management, 5(11): 97-105.

Dess, G. G., Lumpkin, G. T. \& Taylor, M. L. (2005). Strategic management. (2nd Ed.). New York: McGraw-Hill Irwin.

Dudin, A.Y. (2013). Challenges facing the application of strategic management in Arabic business organizations: The case of telecom sector in Jordan. European Journal of Social Sciences, 37(1): 111-120.

Dauda, Y. A., Akingbade, W. A., \& Akinlabi, H. B. (2010). Strategic management practice and corporate performance of selected small business enterprises in Lagos Metropolis. International Journal of Business and Management Vol. 5, No. 11; November 2010.

David, H. H. (2005). The impact of strategic management on organizational growth and development.

Farah, I. M. (2012). The impact of strategic management on organizational growth and development: Achievements, challenges and opportunities.

Griffin. (2006). Effect of strategic issue management on organisational performance. Transnational Journal of Science and Technology.

Lawal, F. M., Elizabeth, O. O., \& Oludayo, O. (2012). Effect of strategic issue management on organizational performance. Transnational Journal of Science and Technology November 2012 edition vol. 2, No. 10.

Muogbo, U. S. (2013). The impact of strategic management on organizational growth and development (A study of selected manufacturing firms in Anambra State). IOSR Journal of Business and Management (IOSR-JBM) ISSN: 2278487X. Volume 7, Issue 1 (Jan. - Feb. 2013), PP 24-32.

Price, S. L. (2006). Performance management strategies: A competitive advantage for high technology firms. A Study in the Okanagan Valley Region of British Columbia, Canada. Unpublished Dissertation. Faculty of Business, University of Southern Queensland.

Copyright (ㅇ International Association of African Researchers and Reviewers, 2006-2017: www.afrrevjo.net.

Indexed African Journals Online: www.ajol.info 
Singh, K. (2005). The impact of strategic planning process variation on superior organizational performance in nonprofit human service organizations providing mental health services. Columbia University, Pro Quest, UMI Dissertations Publishing. 3174894. The Jordan Times (2013).

UNDP (2008). Assessment of development results: Evaluation of UNDP contributions. ECUADOR. Evaluation Office, United Nations Development Programme.

Zeglat, D., AlRawabdeh, W., Faisal A. F., \& Shrafat, F. (2012). Performance measurements systems: Stages of development leading to success. Interdisciplinary Journal of Contemporary Research in Business, 4(7): 440-448. 